logos_i_ethos_2019_1_(49), s. 27-43

DOI: http://dx.doi.org/10.15633/lie.3433

Michał Dudek

https://orcid.org/0000-0001-6294-6027

Uniwersytet Jagielloński w Krakowie

\title{
Co by było, gdyby... próbowano nie popełniać błędu naturalistycznego?
}

\section{Wprowadzenie}

Dzieło Principia Ethica George’a Edwarda Moore'a powszechnie jest traktowane jako punkt zwrotny w filozofii. To właśnie jego wydanie w 1903 roku uważa się za początek metaetyki. I mimo że zainteresowania współczesnych metaetyków wybiegają znacznie poza skrupulatne analizy wypowiedzi zawierających orzeczniki etyczne ${ }^{1}$ - na których przecież brytyjski filozof skupia się w swoim traktacie - to jednak jego myśl ciągle stanowi istotny punkt odniesienia aktualnie prowadzonych rozważań. Koncepcją Moore’a, którą do dzisiaj się przywołuje i komentuje nie tylko na gruncie samej etyki, lecz także w innych dziedzinach szeroko pojmowanej humanistyki, jest rzecz jasna słynny błąd naturalistyczny. Choć w niniejszym artykule za przedmiot analiz obrano właśnie błąd naturalistyczny, to już na wstępie trzeba podkreślić, że poniższe rozważania są w istotnym stopniu odmienne od namysłu wielu uczonych nad wspomnianą koncepcją. Mianowicie, nie podejmuje się
Michał Dudek - doktor nauk prawnych, adiunkt w Katedrze Socjologii Prawa Wydziału Prawa i Administracji UJ. Autor monografii Komunikowanie prawa $w$ dobie pluralizmu kulturowego (Kraków 2014), współredaktor kilku prac zbiorowych (ostatnio, z Piotrem Eckhardtem i Marcinem Wróblem, Przestrzenny wymiar prawa, Kraków 2018) oraz publikacji dotyczących m.in. polityki i aksjologii prawa, wizualności i prawa oraz technologii i prawa.

Zob. np. A. Miller, Contemporary Metaethics. An Introduction, Cambridge $2013^{2}$. 
tu krytyki założeń i argumentacji Moore’a, nie dokonuje się wprost różnego rodzaju interpretacji samego błędu naturalistycznego, nie wdaje się $\mathrm{w}$ polemiki z dotychczasowymi komentatorami i interpretatorami tej koncepcji, nie umiejscawia się jej w kontekście już historycznych, jak i aktualnie prowadzonych debat, ani nie zestawia się jej z innymi koncepcjami filozoficznymi. Podnosząc brew w zdziwieniu, można zatem zadać w pełni usprawiedliwione pytanie: jaki dokładnie problem związany $z$ błędem naturalistycznym jest przedmiotem prowadzonych poniżej dociekań? W artykule podejmuje się w zdecydowanej mierze pomijane zagadnienie konsekwencji prób unikania błędu naturalistycznego w codziennych interakcjach ${ }^{2}$. Innymi słowy, za cel obiera się przedstawienie

${ }^{2} \mathrm{~W}$ bogatej literaturze przedmiotu trudno dopatrzeć się podejmowania tego zagadnienia, por. np. J. Solomon, Is the Conception of „Good” Undefinable?, „Proceedings of the Aristotelian Society. New Series" 6 (1905-1906), s. 128-140; D. C. Williams, The Definition of Yellow and of Good, „The Journal of Philosophy” 27 (1930) no. 19, s. 515-527; A. Edel, Further on Good and Its Structure, „The Journal of Philosophy” 27 (1930) no. 26, s. 701-708; D. C. Williams, The Meaning of , Good", „The Philosophical Review” 46 (1937) no. 4, s. 416-423; W. K. Frankena, The Naturalistic Fallacy, „Mind. New Series” 48 (1939) no. 192, s. 464-477; G. R. Geiger, A Note on the Naturalistic Fallacy, „Philosophy of Science” 16 (1949) no. 4, s. 336-342; J. J. Fisher, On Defining Good, „The Journal of Philosophy” 51 (1954) no. 23, s. 730-736; B. J. Diggs, On Defining „Good”, „The Journal of Philosophy” 54 (1957) no. 15, s. 457-466; P. Glassen, Moore and the Indefinability of Good, „The Journal of Philosophy" 55 (1958) no. 10, s. 430-435; R. S. Hartman, The Definition of Good: Moore's Axiomatic of the Science of Ethics, „Proceedings of the Aristotelian Society. New Series” 65 (19641965), s. 235-256; D. P. Gauthier, Moore's Naturalistic Fallacy, „American Philosophical Quarterly” 4 (1967) no. 4, s. 315-320; S. Jedynak, Błąd naturalistyczny, „Etyka” 2 (1967), s. 289-297; B. H. Baumrin, Is There a Naturalistic Fallacy?, "American Philosophical Quarterly” 5 (1968) no. 2, s. 79-89; G. O. Allen, From the „Naturalistic Fallacy” to the Ideal Observer Theory, „Philosophy and Phenomenological Research" 30 (1970) no. 4, s. 533-549; C. Lewy, G. E. Moore on the Naturalistic Fallacy, w: G. E. Moore. Essays in Retrospect, ed. A. Ambrose, M. Lazerowitz, London 1970, s. 292303; W. H. Bruening, Moore and „Is-Ought”, „Ethics” 81 (1971) no. 2, s. 143-149; K. Nielsen, Covert and Overt Synonymity: Brandt and Moore and the „Naturalistic Fallacy”, „Philosophical Studies: An International Journal for Philosophy in the Analytic Tradition" 25 (1974) no. 1, s. 51-56; A. Kolnai, The Ghost of the Naturalistic Fallacy, „Philosophy” 55 (1980) no. 211, s. 5-16; J. Kovesi, "Principia Ethica” Re-examined: The Ethics of a Proto-logical Atomism, „Philosophy” 59 (1984) no. 228, s. 157-170; R. P. Sylvester, The Moral Philosophy of G.E. Moore, ed. R. Perkins, Jr., R. W. Sleeper, Philadelphia 1990, zwłaszcza s. 157-184; W. H. Shaw, Moore on Right and Wrong. The Normative Ethics of G. E. Moore, Dordrecht 1995, zwłaszcza s. 9-14; T. Baldwin, G. E. Moore. The Arguments of the Philosophers, London 1999, zwłaszcza s. 66-110; P. Clark, The Meaning of „Good” and the Possibility of Value, „Philosophical Studies: An International Journal for Philosophy in the Analytic 
podstawowych sposobów unikania błędu naturalistycznego i ich prawdopodobnych skutków w komunikacji międzyludzkiej. Wybór tak zarysowanego zadania jest podyktowany przede wszystkim dwoma, chyba dość trywialnymi wnioskami, które mogą się nasunąć przy lekturze Principia Ethica.

Jak powszechnie wiadomo, Moore oskarża wielu swoich poprzedników, wybitnych filozofów o popełnianie błędu naturalistycznego. W żadnej mierze jednak nie odnosi się do występowania tego błędu u „zwykłych” ludzi. Codzienne doświadczenia komunikacji międzyludzkiej raczej usprawiedliwiają postawienie tezy, iż wyjaśnianie właściwości dobra przypisywanej danemu obiektowi przez wymienienie innych cech tego obiektu, jest nagminne. Można powiedzieć, że nie ma w tym nic nadzwyczajnego. Jeśli wielcy myśliciele popełniają ten błąd, to z pewnością czynią to również pozostali ludzie. Ponadto, gdy określa się dane postępowanie jako błędne, oczywista zdaje się potrzeba rozważenia sposobów unikania takiego działania, a także ich prawdopodobnych praktycznych konsekwencji. Jeśli coś charakteryzowane jest jako nagminny błąd, to być może warto próbować tego nie czynić.

Antycypując poniższe uwagi, można powiedzieć, że przewidywane skutki podstawowych sposobów unikania błędu naturalistycznego mogą budzić poważne wątpliwości z perspektywy ogólnie pojmowanej pragmatyki komunikacji międzyludzkiej i powszechnej praktyki użycia języka. Zanim szczegółowo zaprezentuje się możliwe

Tradition” 108 (2002) no. 1/2, s. 31-38; W. Załuski, Błąd naturalistyczny, w: Studia z filozofii prawa, t. 2, red. J. Stelmach, Kraków 2003, s. 111-121; B. Hutchinson, G. E. Moore's Ethical Theory. Resistance and Reconciliation, Cambridge 2004, passim; P. Stratton-Lake, G. E. Moore: „Principia Ethica", w: Central Works of Philosophy Volume 4. The Twentieth Century: Moore to Popper, ed. J. Shand, Chesham 2006, s. 20-37; J. Jurkiewicz, Byt a powinność jako relacja egzystencjalna i formalno-analityczna, „Czasopismo Filozoficzne” 6 (2010), s. 13-32; A. Niemczuk, Błąd teoretyzmu w aksjologii, „Kultura i Wartości” 3 (2012), s. 7-35; A. Brożek, Błąd naturalistyczny $z$ metodologicznego punktu widzenia, w: A. Brożek, B. Brożek, J. Stelmach, Fenomen normatywności, Kraków 2013, s. 153-177; A. Miller, Contemporary Metaethics..., dz. cyt., rozdz. 2; Ł. Kurek, Zarzut błędu naturalistycznego i jego wpływ na dwudziestowieczna metaetykę, w: Naturalizm prawniczy. Stanowiska, red. J. Stelmach, B. Brożek, Ł. Kurek, K. Eliasz, Warszawa 2015, s. 94-111; Ł. Kurek, Naturalistic Fallacy, „Polish Law Review” 3 (2017) no. 1, s. 242-258. 
do zidentyfikowania kontrowersje, warto przypomnieć oryginalne ujęcie błędu naturalistycznego.

\section{Kilka słów o błędzie naturalistycznym}

Moore twierdzi, że szereg problemów, sporów i nieporozumień występujących w historii filozofii jest wynikiem zaniedbywania dokładnego określenia pytania, na które chce się odpowiedzieć, zrozumienia problemu, który chce się rozwiązać ${ }^{3}$. W jego przekonaniu przykładem takiego nieprzeanalizowanego pytania jest: „co jest dobre?”. Oczywiście, może ono być interpretowane na kilka sposobów. Mianowicie, można je odnosić do przedmiotów, którym przysługuje właściwość dobra, bądź samego rozumienia pojęcia dobry. Pytanie „co znaczy dobry?”, a więc ta druga interpretacja, jest w jego przekonaniu zasadniczym przedmiotem dociekań z zakresu etyki ${ }^{4}$. Po rozpatrzeniu kilku możliwych sposobów definiowania Moore dochodzi do wniosku, że cecha dobra jest niedefiniowalna $z$ perspektywy przyjętego przez niego definiowania przez „części składowe” danych przedmiotów ${ }^{5}$. Właściwość dobra uważa bowiem za prostą i nieredukowalną do czegokolwiek innego. Choć sama cecha dobra nie poddaje się definiowaniu, to inne ogólnie pojmowane obiekty - materialne, niematerialne, etycznej, jak i pozaetycznej „proweniencji” - mogą być z powodzeniem za jej pomocą definiowane. Moore chce bowiem wyraźnie zaznaczyć istotną różnicę między właściwością określaną mianem dobra a obiektami, które można charakteryzować przez tę cechę ${ }^{6}$. Innymi słowy, samo pojęcie dobra jest niedefiniowalne, ale wcale nie oznacza to, że obiekty, które można za jego pomocą charakteryzować, same nie mogą być poddane definiowaniu. Są one bowiem złożonymi, a nie prostymi bytami, jak cecha dobra ${ }^{7}$.

3 Zob. G. E. Moore, Zasady etyki, tłum. C. Znamierowski, Warszawa 2003, s. V.

4 Zob. G. E. Moore, Zasady etyki, dz. cyt., s. 7-8.

5 Zob. G. E. Moore, Zasady etyki, dz. cyt., s. 12-13.

${ }^{6}$ Zob. G. E. Moore, Zasady etyki, dz. cyt., s. 13-14.

7 Zob. G. E. Moore, Zasady etyki, dz. cyt., s. 15. 
Zobrazowaniem tej tezy jest następująca wypowiedź autora Principia Ethica: „«dobry» jest pojęciem prostym podobnie jak «żółty»; tak jak nie można w żaden absolutnie sposób wyjaśnić komuś, kto nie zna barwy żółtej, co to jest «żółty», podobnie nie można wyjaśnić, co to jest dobry"8. Przyrównywanie właściwości dobra przypisywanej określonym obiektom do właściwości koloru, jakimi mogą być one również charakteryzowane, zdaje się być konsekwencją stanowiska bronionego przez Moore’a, zgodnie z którym twierdzenia etyczne są w zasadzie takie same jak inne twierdzenia o rzeczywistości - można je zasadnie oceniać w kategoriach prawdy bądź fałszu. Dla brytyjskiego myśliciela szczególnie istotna jest oczywistość sama przez się danych wypowiedzi. Wypowiedź jest oczywista sama przez się, jeśli dla jej autora bądź adresata zdaje się być prawdziwa „sama z siebie” - by uznać ją za prawdziwą, nie potrzeba odwoływać się do żadnej innej wypowiedzi ${ }^{9}$. Można wręcz powiedzieć, że w takim ujęciu prawdziwość danego twierdzenia, także określającego dany obiekt jako dobry, zależy po prostu od stopnia, w jakim „przemawia" ono do określonej osoby. Zatem, podobnie jak osoba widząca nie może skutecznie wytłumaczyć osobie niewidomej od urodzenia, czym jest kolor żółty, tak nie można uzasadnić twierdzenia, iż dany obiekt jest dobry, osobie, która sama tak nie uważa.

Dobro, jako właściwość przypisywana różnym obiektom, nie poddaje się definiowaniu. Jest cechą prostą, jednorodną, nieskładającą się z żadnych pomniejszych elementów, które można by wskazać $\mathrm{w}$ jej definicji. Zdaniem Moore’a wskazywanie innych cech przysługujących obiektom mającym właściwość dobra nie jest definiowaniem samej cechy dobra. Błędem naturalistycznym - $\mathrm{w}$ jego oryginalnym sformułowaniu - jest więc każda próba wyjaśnienia, czym jest właściwość dobra poprzez inne cechy przysługujące obiektom, które wcześniej określono jako dobre ${ }^{10}$.

8 G. E. Moore, Zasady etyki, dz. cyt., s. 10-11.

9 Zob. G. E. Moore, Zasady etyki, dz. cyt., s. 229-230.

10 Zob. G. E. Moore, Zasady etyki, dz. cyt., s. 16. 


\section{Zarys sytuacji wyjściowej (SW)}

W celu wyeksplikowania możliwych konsekwencji podejmowania prób uniknięcia błędu naturalistycznego warto wyobrazić sobie ogólnie pojętą dyskusję toczącą się między dwoma stronami. Taką przykładową sytuacją wyjściową (SW) może być debata na temat określonego zagadnienia polityki społecznej. Uczestniczą w niej przedstawiciele dwóch opozycyjnych ugrupowań politycznych: X i Y. Pierwszy z nich, X, prezentując stanowisko swojego ugrupowania, omawia jeden z postulatów, który można umownie oznaczyć jako $a$. Ta na razie bardzo ogólnie zarysowana SW, która przecież znajduje odzwierciedlenie i konkretyzację w życiu codziennym - chodzi wszak o szeroko pojmowaną rozmowę po dokonaniu odpowiednich uzupełnień, pozwala rozważyć praktyczne problemy związane $\mathrm{z}$ błędem naturalistycznym i próbami uniknięcia tego błędu. Jak już sugerowano powyżej, szczególny nacisk położono na prawdopodobny przebieg faktycznych interakcji międzyludzkich, nie ograniczając się tu w żadnej mierze do dyskusji politycznych czy akademickich.

\section{Pierwszy wariant (W1) - „...jest dobre, bo jest efektywne”}

W pierwszym wariancie (W1), uzupełniającym zdawkowo zarysowaną SW, dochodzi do popełnienia błędu naturalistycznego. Wpierw $\mathrm{X}$ twierdzi, że a jest dobre. Oczywiście, posługuje się on tutaj pewnym skrótem myślowym. Nie chodzi bowiem o to, że sama jego wypowiedź opisująca daną reformę polityki społecznej jest dobra. Właściwość dobra przypisuje on przewidywanym społecznym konsekwencjom przeprowadzenia nowelizacji proponowanej przez jego opcję polityczną. Y - reprezentant konkurencyjnego ugrupowania uczestniczącego w debacie - prosi o uzasadnienie stanowiska, zgodnie z którym a jest dobre. Zadawane przez Y pytania mogą przybrać różną formę, np.: „w jakim sensie a jest dobre?” bądź po prostu „dlaczego a jest dobre?”. X, starając się odpowiedzieć na pytanie $\mathrm{Y}$, uzasadnić głoszony przez siebie pogląd, iż a jest dobre, popełnia błąd naturalistyczny. Mianowicie, 
$\mathrm{X}$ mówi, że a jest dobre, gdyż jest ono m.in. efektywne ekonomicznie czy nieszkodliwe dla środowiska naturalnego.

Wydaje się, że w świetle argumentacji Moore’a dotyczącej błędu naturalistycznego, $\mathrm{w}$ omawianym wariancie $\mathrm{X}$ tak naprawdę wcale nie odpowiada na zadane pytanie. Wszak a traktuje się jako przewidywane skutki przeprowadzenia danej reformy. X przypisuje a właściwość dobra. Y pyta dokładnie, dlaczego a jest dobre. X, twierdząc, że a jest dobre, gdyż jest m.in. efektywne ekonomicznie czy nieszkodliwe dla środowiska naturalnego, zgodnie z ustaleniami Moore’a w żaden sposób nie przybliża właściwości dobra, jakie rzekomo przysługuje obiektowi będącemu przedmiotem dyskusji. Wspomniane właściwości ekonomicznej efektywności oraz nieszkodliwości dla środowiska naturalnego są tylko kolejnymi z całego szeregu cech, którymi można charakteryzować określony obiekt, jak, w omawianym przypadku, przewidywane konsekwencje przeprowadzenia danej reformy. X w swojej wypowiedzi następującej po pytaniu „dlaczego a jest dobre?” dokonuje dokładniejszego opisu omawianego obiektu. Postulat a (a właściwie jego przewidywane konsekwencje) jest określany już nie tylko przez prostą, niedefiniowalną i niepoddającą się analizie właściwość dobra, ale także przez dodatkowe cechy. Wydaje się więc, że X popełnia w W1 błąd naturalistyczny. Zdaje się on utożsamiać prostą właściwość dobra $\mathrm{z}$ innymi właściwościami przysługującymi obiektowi, który określa jako dobry.

\section{Drugi wariant (W2) - „...jest dobre i tyle!”}

Po zaprezentowaniu W1, w którym dochodzi do popełnienia błędu naturalistycznego, warto zastanowić się nad jednym ze sposobów jego uniknięcia. W tym celu użyteczny jest drugi wariant (W2), w wielu punktach zbieżny z W1. X twierdzi, że a jest dobre. Y zadaje pytanie, dlaczego $\mathrm{X}$ tak uważa. Jednakże, zamiast wymieniania innych właściwości przypisywanych $\alpha$, prób uargumentowania swojego przekonania, iż obiektowi będącemu przedmiotem dyskusji rzeczywiście przysługuje właściwość dobra, $\mathrm{X}$ w W2 na zadane przez Y pytanie odpowiada po prostu: „a jest dobre i tyle!”. Oczywiście przy podobnej odpowiedzi 
może on dodać, iż w jego przekonaniu dobro a jest czymś oczywistym. Skoro Y pragnie uzasadnienia takiego twierdzenia, to najwidoczniej nie przemawia ono do jego intuicji.

Taki hipotetyczny zabieg X byłby, rzecz jasna, konsekwencją wcześniej opisanego poglądu Moore’a, iż można mówić o prawdziwości bądź fałszywości twierdzeń etycznych w zależności od ich oczywistości samej przez się dla mówcy bądź adresata danej wypowiedzi. X, twierdząc, że a jest dobre, może być w pełni przekonany o prawdziwości swojej wypowiedzi, podobnie jak osoba o zdrowym zmyśle wzroku nie podważa tego, że płatki kwitnących na łące mleczy polnych są żółte. Trzeba jednak zauważyć, że postawa, jaką reprezentuje X w W2, może być w pełni zasadnie potraktowana przez wszystkie podmioty, do których wypowiedź „a jest dobre” nie przemawia, jako przejaw skrajnego wręcz dogmatyzmu i swoistego wywyższania się. Można by w takiej sytuacji odnieść wrażenie, jakoby X był przekonany o swoim lepszym wglądzie w ocenę etyczną różnych obiektów niż wszyscy pozostali, którzy w mniejszym lub większym stopniu nie zgadzają się z jego stanowiskiem. Skoro nie zgadzają się lub mają wątpliwości, które chcieliby rozwiać, są w błędzie.

Dyskusja wedle W2 mogłaby zatem stanąć w martwym punkcie nie tylko $\mathrm{z}$ prostego powodu, że $\mathrm{X}$ w zasadzie nie odpowiada na zadane przez Y pytanie. Y uświadomiwszy sobie doktrynerstwo swojego interlokutora, może w swojej ripoście argumentować, że to $\mathrm{X}$ tak naprawdę się myli. Z własnej perspektywy Y może bowiem twierdzić, że to jego własna intuicja jest słuszna. Skoro do Y nie przemawia twierdzenie, iż a jest dobre, to najpewniej jest ono po prostu fałszywe. Zatem w przekonaniu Y myli się X, choć on sam może być wciąż przekonany o słuszności swojego twierdzenia, lecz unikać argumentacji na jego rzecz, by nie popełnić błędu naturalistycznego. Jak już zatem łatwo sobie wyobrazić, w takiej „dyskusji” jej uczestnikom bardzo łatwo może "umknąć" pierwotnie zakładany cel rozmowy. Ona sama może przerodzić się we wzajemne przekrzykiwanie się zacietrzewionych interlokutorów wymieniających się krótkimi hasłami typu: „a jest dobre!” oraz „nie, nieprawda!". Usprawiedliwiona zdaje się zatem teza, że opisywana w W2 próba uniknięcia błędu naturalistycznego może mieć bardzo negatywne 
konsekwencje dla ogólnie pojmowanej komunikacji międzyludzkiej, niezależnie od kontekstu prowadzonej rozmowy. $Z$ drugiej strony jednak możliwe jest bardziej optymistyczne spojrzenie na dyskutantów i twierdzenie, że przy ich odpowiednim „poziomie” potraktują rozbieżność między sobą jako wskaźnik ich odmiennych intuicji etycznych, które można poddać dalszej dyskusji i próbie zrozumienia. Pozostaje jednak empiryczne pytanie: co jest częstsze w praktyce? Dyskutanci zbliżający się w swoim usposobieniu np. do wymogów określonej normatywnej etyki mowy, czy mniej lub bardziej dyskursywnie niedoskonali i tym samym mogący swoimi zachowaniami wypaczyć przebieg komunikacji między nimi, a nawet ją w konsekwencji zerwać?

\section{Trzeci wariant (W3) - brak pytania „dlaczego?”}

Negatywne skutki dla przykładowej dyskusji opisane w poprzednim punkcie można traktować jako konsekwencje dwóch działań podjętych przez uczestniczących w niej interlokutorów: (1) Y zadaje pytanie „dlaczego a jest dobre?"; (2) X w swojej wypowiedzi następującej po pytaniu Y stara się za wszelką cenę uniknąć błędu naturalistycznego. Wydaje się jednak, że istnieje kolejny, nie mniej kontrowersyjny sposób uniknięcia tego błędu w zaprezentowanej powyżej SW, który można wyeksplikować, proponując jej trzeci wariant $\left(\mathrm{W}_{3}\right)$. W tym wariancie, podobnie jak w W1 oraz W2, X twierdzi, że a jest dobre. Tym razem jednak, przeciwna strona $\mathrm{w}$ dyskusji, $\mathrm{Y}$ wcale nie zwraca się z prośbą o uzasadnienie wygłoszonego twierdzenia. Nie zadaje pytania, „w jakim sensie a jest dobre?” ani po prostu „dlaczego a jest dobre?” Oczywiście, w przypadku gdy Y zgadza się z X - sam uważa, iż rzeczywiście a jest dobre - brak podobnych pytań jest w pełni zrozumiały. Sytuacja jest jednak zdecydowanie bardziej problematyczna w przypadku, gdy Y nie zgadza się z X. Jak pokazują $\mathrm{W}_{1}$ i W2, pytania o uzasadnienia głoszonego poglądu, że określony obiekt jest dobry, mogą prowadzić, odpowiednio: (ad W1) do popełnienia przez interlokutora błędu naturalistycznego bądź (ad W2) do znacznego utrudnienia merytorycznej dyskusji, w przypadku gdy spytany rozmówca pragnie uniknąć wspomnianego błędu. 
Każdy, kto twierdzi, że dany obiekt jest dobry i uważa tę wypowiedź za prawdziwą z uwagi na jej oczywistość samą przez się, sam nie czuje rzecz jasna potrzeby uzasadnienia takiej tezy, więc w zasadzie nie ma ryzyka, że popełni błąd naturalistyczny. Może być on jednak w swoisty sposób sprowokowany, by go popełnić, gdy ktoś poprosi o przedstawienie racji przemawiających za głoszonym twierdzeniem. W3 zdaje się więc dobitnie pokazywać, iż to, czy ktoś popełni błąd naturalistyczny, w dużej mierze zależy od postępowania osób, które w taki lub inny sposób „usłyszały”, iż dany obiekt jest wedle czyjejś opinii dobry, ale same z tym twierdzeniem się nie zgadzają lub go w pełni nie rozumieją. Można chyba z dużą dozą pewności zakładać, że gdy jeden z podmiotów uczestniczących w dyskusji głosi, iż dany obiekt jest w jego przekonaniu dobry, a wszyscy pozostali uczestnicy debaty zgadzają się z tym twierdzeniem, nikt nie zada pytania „dlaczego jest dobry?”. Skoro wszyscy tak uważają, to raczej nikt nie potrzebuje uzasadnienia ani wytłumaczenia takiego stanowiska. Trudno jednak oczekiwać, by osoby niezgadzające się lub nierozumiejące twierdzenia, iż dany obiekt jest dobry, nie prosiły o uzasadnienie takiej tezy, nie zadawały pytania "dlaczego?” tylko w tym celu, by zapewnić „dyskurs wolny od błędu naturalistycznego”. Wydaje się więc, że próby uniknięcia tego błędu przez niewypowiadanie sformułowań mogących sprowokować popełnienie go są w dużej mierze nierealistyczne i mogą zubożyć dyskusje.

\section{Czwarty wariant (W4) - unikanie używania orzecznika „dobry”}

Trzeba jednak zaznaczyć, że zasadniczym źródłem omawianych powyżej problemów nie są jedynie prośby o uzasadnienie głoszonych twierdzeń, lecz także samo używanie orzecznika „dobry”. Można powiedzieć, że jego wystąpienie w wypowiedzi jest warunkiem koniecznym, lecz niewystarczającym popełnienia błędu naturalistycznego. Wydaje się więc, że najskuteczniejszym sposobem uniknięcia tego błędu jest po prostu unikanie określania danych obiektów jako dobre. Zgodnie z tymi ustaleniami, w czwartym wariancie (W4) X, opisując zgłaszany przez swoją opcję polityczną postulat $\alpha$, nie używa orzecznika „dobry”. Zamiast tego 
a jest definiowane jako m.in. efektywne ekonomiczne czy nieszkodliwe dla środowiska naturalnego. Jeśli orzecznik „dobry” nie pojawi się w dalszej dyskusji między X a Y, to błąd naturalistyczny nie będzie mógł być popełniony.

Chociaż zaproponowany w $\mathrm{W}_{4}$ sposób unikania błędu naturalistycznego przez nieużywanie orzecznika „dobry”, na tle sposobów wskazywanych w W2 i W3, zdaje się być najskuteczniejszy, to jego praktyczna realizacja również stoi pod dużym znakiem zapytania. Trzeba bowiem zastanowić się, w jakim stopniu możliwe jest powszechne unikanie używania orzecznika „dobry” w różnych wypowiedziach. Wydaje się, że daleko posunięta rezygnacja $\mathrm{z}$ tak zasadniczego i niezmiernie często używanego określenia jest nierealistyczna.

\section{Zakończenie}

Już tylko te powyższe opisy ukazują, jakie konsekwencje dla komunikacji międzyludzkiej może mieć unikanie błędu naturalistycznego. Można je uznać za co najmniej kontrowersyjne, takie, na które chyba niewiele osób byłoby gotowych wyrazić zgodę. Trudno bowiem z całą powagą oczekiwać, że w imię samego niepopełniania błędu naturalistycznego zrezygnuje się np. z prób uzasadniania głoszonych twierdzeń czy posługiwania się orzecznikiem „dobry”. Co należy dodatkowo podkreślić, wydaje się, że sygnalizowane praktyczne problemy są całkowicie niezależne od samej oceny argumentacji Moore’a na temat błędu naturalistycznego, np. od tego, czy Moore faktycznie zidentyfikował rzeczywisty błąd, czy też błąd naturalistyczny jest jedynie wynikiem przyjętych przez niego założeń dotyczących m.in. prawidłowego sposobu definiowania pojęć. Mianowicie unikanie wyjaśniania właściwości dobra poprzez wymienianie innych cech przysługujących obiektom wcześniej określonych jako dobre, cech których wystąpienie w danym przedmiocie wcale nie musi zawsze przesądzać o jego dobru (np. efektywność ekonomiczna może prowadzić wręcz do zaprzeczenia dobra), raczej zawsze będzie powodowało problemy w komunikacji, niezależnie od tego, czy tego typu wyjaśnianie będzie ocenione jako błędne czy poprawne. Powyższe 
rozważania, choć dalekie od wyczerpania zagadnienia ewentualnych sposobów i skutków unikania błędu naturalistycznego, zwracają uwagę na w zasadzie całkowicie pomijany praktyczny aspekt słynnej koncepcji Moore’a, uwidaczniający się, gdy przestanie się ją odnosić wyłącznie do dyskursu par excellence filozoficznego, a zacznie się analizować w sytuacjach dnia codziennego.

Dla uczciwości polemicznej należy jednak zaznaczyć, że do zasugerowanego w niniejszym artykule problemu i jego konceptualizacji można podejść zupełnie inaczej. Niewykluczone jest przecież odwołanie się do szeregu niejasności w argumentacji Moore’a i tego, jakie stanowiska wokół nich narosły w ciągu długiej dyskusji nad błędem naturalistycznym. Nawiązując do mnogości kierunków interpretacji wywodu Moore’a, ale i jego własnych słów ${ }^{11}$, możliwe jest podnoszenie, przykładowo, że X uzasadniający „a jest dobre” przez ekonomiczną efektywność a (W1) wcale nie utożsamia „dobry” z „efektywny ekonomicznie” - nie wyjaśnia pierwszej właściwości przez drugą. Traktuje natomiast obie te cechy jako odrębne, ale przysługujące jednemu przedmiotowi, o którym orzeka. Innymi słowy, ekonomiczna efektywność (czy w zasadzie jakikolwiek inny predykat określany mianem nieetycznego), może być, z perspektywy podmiotu wypowiadającego analizowane twierdzenia, traktowana jako silnie pozytywnie skorelowana $\mathrm{z}$ cechą dobra, ale jej samej nietłumacząca. Można zatem argumentować na rzecz wyraźnego odróżniania korelacji i utożsamiania oraz stosownie twierdzić, iż do błędu naturalistycznego dochodzi przy potraktowaniu jakiegoś innego orzecznika (np. naturalnego, empirycznego) jako tożsamego z orzecznikiem „dobry”, ale już nie wtedy, gdy uzna się je oba za silnie ze sobą pozytywnie skorelowane (współwystępujące) w danym przedmiocie. Oczywiście można powiedzieć, że praktyczne stwierdzenie, z którą sytuacją ma się do czynienia, jest ostatecznie zależne od uzyskania wglądu w założenia podmiotów wypowiadających analizowane sądy. Takie pragmatyczne spojrzenie na zaproponowaną SW i jej warianty można rozwijać. Sposoby wytłumaczenia, czy też presupozycje X mówiącego „a jest

11 Zob. G. E. Moore, Zasady etyki, dz. cyt., s. 16. 
dobre" i w określony sposób rozwijającego swoje twierdzenie, mogą być jeszcze bardziej różnorodne i tym samym komplikujące kwalifikowanie pewnych zachowań jako przypadki błędu naturalistycznego. „a jest dobre”, obok tego, że X używa „dobre” jako swoisty generalny skrót myślowy, podczas gdy tak naprawdę ma na myśli jakiś nieetyczny predykat (mówi "dobry”, choć myśli np. „szybki”), może równie dobrze wynikać z błędu, przejęzyczenia. Co więcej, tłumaczenie „ঐ jest dobre” przez wspomnianą efektywność ekonomiczną może być wypowiadane/interpretowane jako przeświadczenie, że a poprzez swoją właściwość „ekonomiczności” wpłynie pozytywnie - w porównaniu do możliwych względem siebie alternatyw - na stan, ilość dobra (ujętego rzeczownikowo), a nie jako wyjaśnienie dobra (ujętego przymiotnikowo, jako możliwa właściwość przypisywana obiektom) przez jakąś inną cechę. Już same wypowiedzi $\mathrm{X}$ dają się więc ująć $\mathrm{z}$ wielu różnych perspektyw. Podobnej procedurze można także poddać wypowiedzi $\mathrm{Y}$, w ramach której zasadnicze „dlaczego a jest dobre?" może być uznane już nie za pytanie o wytłumaczenie orzecznika „dobry”, ale np. o wyjaśnienie jakiejś innej cechy, którą Y ma na myśli, lecz w swojej wypowiedzi odwołanie się do niej wprost zastępuje przez ogólniejsze słowo „dobry”.

Nie ma konieczności przedstawiania kolejnych możliwych spojrzeń na codzienne interakcje, wniosek jest ten sam: każde z nich może dawać inne wyniki. Mianowicie, w świetle niektórych perspektyw rozmowy podobne do tych naszkicowanych powyżej mogą być ocenione jako naznaczone tym, co Moore nazwał błędem naturalistycznym, podczas gdy inne interpretacje nie będą już prowadziły do takiej konkluzji. Mogą być więc także odczytywane jako sugestie wielu innych metod unikania błędu naturalistycznego. Zastrzegając to, trzeba jednak podkreślić zasadniczy wniosek, że działanie opisane przez Moore’a jako błędne może być ujmowane w kontekście codziennych interakcji, użycia w nich określenia "dobry” i ewentualnego uzasadniania sądów je zawierających. Co więcej, taka specyficzna, z perspektywy dominującego sposobu rozprawiania o słynnej idei Moore’a, kontekstualizacja błędu naturalistycznego zdaje się także umożliwiać dostrzeżenie nowych płaszczyzn jego analizy. Przykładem tego jest właśnie problematyka ewentualnych skutków 
różnych sposobów unikania wyjaśniania właściwości dobra przez inne cechy obiektów, wcześniej określonych jako dobre.

\section{Bibliografia}

Allen G. O., From the „Naturalistic Fallacy” to the Ideal Observer Theory, „Philosophy and Phenomenological Research" 30 (1970) no. 4, s. 533-549.

Baldwin T., G. E. Moore. The Arguments of the Philosophers, London 1999.

Baumrin B. H., Is There a Naturalistic Fallacy?, „American Philosophical Quarterly” 5 (1968) no. 2, s. 79-89.

Brożek A., Błąd naturalistyczny z metodologicznego punktu widzenia, w: A. Brożek, B. Brożek, J. Stelmach, Fenomen normatywności, Kraków 2013, s. 153-177.

Bruening W. H., Moore and „Is-Ought”, „Ethics” 81 (1971) no. 2, s. 143-149.

Clark P., The Meaning of „Good' and the Possibility of Value, „Philosophical Studies:

An International Journal for Philosophy in the Analytic Tradition" 108 (2002) no. 1/2, s. 31-38.

Diggs B. J., On Defining „Good”, „,The Journal of Philosophy” 54 (1957) no. 15, s. 457-466. Edel A., Further on Good and Its Structure, „The Journal of Philosophy” 27 (1930) no. 26, s. 701-708.

Fisher J. J., On Defining Good, „The Journal of Philosophy” 51 (1954) no. 23, s. 730-736. Frankena W. K., The Naturalistic Fallacy, „Mind. New Series” 48 (1939) no. 192, s. 464-477. Gauthier D. P., Moore’s Naturalistic Fallacy, „American Philosophical Quarterly” 4 (1967) no. 4, s. 315-320.

Geiger G. R., A Note on the Naturalistic Fallacy, „Philosophy of Science” 16 (1949) no. 4, s. 336-342.

Glassen P., Moore and the Indefinability of Good, „The Journal of Philosophy” 55 (1958) no. 10 , s. $430-435$.

Hartman R. S., The Definition of Good: Moore's Axiomatic of the Science of Ethics, „Proceedings of the Aristotelian Society. New Series" 65 (1964-1965), s. 235-256.

Hutchinson B., G. E. Moore's Ethical Theory. Resistance and Reconciliation, Cambridge 2004.

Jedynak S., Błąd naturalistyczny, „Etyka” 2 (1967), s. 289-297.

Jurkiewicz J., Byt a powinność jako relacja egzystencjalna i formalno-analityczna, "Czasopismo Filozoficzne” 6 (2010), s. 13-32. 
Kolnai A., The Ghost of the Naturalistic Fallacy, „Philosophy” 55 (1980) no. 211, s. 5-16.

Kovesi J., "Principia Ethica” Re-examined: The Ethics of a Proto-logical Atomism, „Philosophy” 59 (1984) no. 228, s. 157-170.

Kurek Ł., Naturalistic Fallacy, „Polish Law Review” 3 (2017) no. 1, s. 242-258.

Kurek Ł., Zarzut błędu naturalistycznego i jego wptyw na dwudziestowieczna metaetyke, w: Naturalizm prawniczy. Stanowiska, red. J. Stelmach, B. Brożek, Ł. Kurek, K. Eliasz, Warszawa 2015, s. 94-111.

Lewy C., G. E. Moore on the Naturalistic Fallacy, w: G. E. Moore. Essays in Retrospect, ed. A. Ambrose, M. Lazerowitz, London 1970, s. 292-303.

Miller A., Contemporary Metaethics. An Introduction, Cambridge $2013^{2}$.

Moore G. E., Zasady etyki, tłum. C. Znamierowski, Warszawa 2003.

Niemczuk A., Błąd teoretyzmu w aksjologii, „Kultura i Wartości” 3 (2012), s. 7-35.

Nielsen K., Covert and Overt Synonymity: Brandt and Moore and the „Naturalistic Fallacy”, „Philosophical Studies: An International Journal for Philosophy in the Analytic Tradition" 25 (1974) no. 1, s. 51-56.

Shaw W. H., Moore on Right and Wrong. The Normative Ethics of G. E. Moore, Dordrecht 1995.

Solomon J., Is the Conception of „Good” Undefinable?, „Proceedings of the Aristotelian Society. New Series" 6 (1905-1906), s. 128-140.

Stratton-Lake P., G. E. Moore: „Principia Ethica”, w: Central Works of Philosophy Volume 4. The Twentieth Century: Moore to Popper, ed. J. Shand, Chesham 2006, s. 20-37.

Sylvester R. P., The Moral Philosophy of G. E. Moore, ed. R. Perkins, Jr., R. W. Sleeper, Philadelphia 1990.

Williams D. C., The Definition of Yellow and of Good, "The Journal of Philosophy” 27 (1930) no. 19, s. 515-527.

Williams D. C., The Meaning of „Good”, „The Philosophical Review” 46 (1937) no. 4, s. $416-423$.

Załuski W., Błąd naturalistyczny, w: Studia z filozofii prawa, t. 2, red. J. Stelmach, Kraków 2003, s. 111-121. 


\section{Abstrakt \\ Co by było, gdyby... próbowano nie popełniać błędu naturalistycznego?}

Artykuł omawia możliwe skutki unikania błędu naturalistycznego (BN) w komunikacji międzyludzkiej. Zarysowana jest hipotetyczna rozmowa dwóch podmiotów (X i Y) na temat przedmiotu ( $\alpha$ ) i sprecyzowane są jej warianty. W 1. wariancie X twierdzi, że $a$ jest dobre, a Y zadaje pytanie, dlaczego jest dobre. X odpowiada, iż a jest dobre, bo jest, np. efektywne ekonomicznie. To można ocenić, zgodnie z podstawowo ujętymi poglądami Moore'a, jako przykład BN. W 2. wariancie X unika odpowiedzi na pytanie Y. X mówi tylko „a jest dobre i tyle!”, co można uznać za nawiązanie do Moore’owskiej kategorii oczywistości samej przez się. Choć $\mathrm{X}$ unika BN, to utrudnia rozmowę. Unikać BN można też przez: niezadawanie pytania „dlaczego a jest dobre?” (wariant 3) czy nieużywanie słowa „dobry” (wariant 4). Analiza wszystkich wariantów pokazuje, że unikanie BN może mieć problematyczne skutki z powodu, m.in., powszechnego użycia słowa „dobry” czy częstej potrzeby, by uzasadnić tezy o przysługującej czemuś cesze dobra. Te konsekwencje zdają się być niezależne od samej oceny argumentacji Moore’a o BN, np., kontrowersji, czy BN jest rzeczywistym błędem czy wynikiem przyjętych przez Moore’a założeń o, m.in., definicjach.

\section{Słowa kluczowe}

metaetyka, George Edward Moore, błąd naturalistyczny, unikanie błędu naturalistycznego, komunikacja międzyludzka

\section{Abstract}

\section{What If... One Tried Not to Commit a Naturalistic Fallacy?}

The paper discusses possible consequences of avoiding naturalistic fallacy (NF) in interpersonal communication. The hypothetical conversation between two subjects ( $\mathrm{X}$ and Y) about an object ( $\alpha$ ) is outlined and its variants are specified. In the variant $1, \mathrm{X}$ states that $\alpha$ is good and $Y$ asks question, why it is good. $X$ says that $\alpha$ is good, because, e.g., it is economically effective. This can be regarded, according to basically understood Moore's view, as an instance of NF. In the variant $2, \mathrm{X}$ avoids answering the Y's question. $\mathrm{X}$ is 
saying only ' $\alpha$ is good and that's it!', which can be interpreted as a reference to Moorean self-evidence category. Although X avoids NF, it impairs a conversation. One can also avoid NF through: not asking 'why a is good?' (variant 3) or not using word 'good' (variant 4). Analysis of all variants shows that avoiding NF can have troublesome consequences because of, i.a., common use of the word 'good' or frequent need to justify statements about goodness of some object. Those consequences seem to be independent from the mere evaluation of Moore's argumentation about NF, e.g., a controversy whether NF is a real fallacy or only a consequence of Moore's assumptions regarding, i.a., definitions.

\section{Keywords}

metaethics, George Edward Moore, naturalistic fallacy, avoidance of naturalistic fallacy, interpersonal communication 